Article

\title{
Evidence of the Presence of Low Pathogenic Avian Influenza A Viruses in Wild Waterfowl in 2018 in South Africa
}

\author{
Marjolein J. Poen $\left.{ }^{1}{ }^{(}\right)$, Ron A. M. Fouchier ${ }^{1}$, Richard J. Webby ${ }^{2}$, Robert G. Webster ${ }^{2}$ and \\ Mohamed E. El Zowalaty $2,3, * \mathbb{D}$ \\ 1 Department of Viroscience, Erasmus Medical Center, Dr. Molewaterplein 50, 3015GE Rotterdam, \\ The Netherlands; m.poen@erasmusmc.nl (M.J.P.); r.fouchier@erasmusmc.nl (R.A.M.F.) \\ 2 Division of Virology, Department of Infectious Diseases, Center of Excellence for Influenza Research and \\ Surveillance (CEIRS), St. Jude Children's Research Hospital, 262 Danny Thomas Place, Memphis, TN 38105, \\ USA; Richard.webby@stjude.org (R.J.W.); Robert.webster@stjude.org (R.G.W.) \\ 3 Virology and Microbiology Research Group, Department of Pharmacy, City University College of Ajman, \\ Sheikh Amaar Road, Al Tallah 2, P.O. Box 18484 Ajman, United Arab Emirates \\ * Correspondence: elzow005@gmail.com or mohamed.ezzat@stjude.org; \\ Tel.: +1-901-595-3414; Fax: +1-901-595-8559
}

Received: 8 August 2019; Accepted: 11 September 2019; Published: 25 September 2019

\begin{abstract}
Avian influenza viruses are pathogens of global concern to both animal and human health. Wild birds are the natural reservoir of avian influenza viruses and facilitate virus transport over large distances. Surprisingly, limited research has been performed to determine avian influenza host species and virus dynamics in wild birds on the African continent, including South Africa. This study described the first wild bird surveillance efforts for influenza A viruses in KwaZulu-Natal Province in South Africa after the 2017/2018 outbreak with highly pathogenic avian influenza virus H5N8 in poultry. A total of 550 swab samples from 278 migratory waterfowl were tested using real-time RT-PCR methods. Two samples $(0.7 \%)$ were positive for avian influenza virus based on the matrix gene real-time RT-PCR but were negative for the hemagglutinin subtypes $\mathrm{H} 5$ and H7. Unfortunately, no sequence information or viable virus could be retrieved from the samples. This study shows that avian influenza viruses are present in the South African wild bird population, emphasizing the need for more extensive surveillance studies to determine the South African avian influenza gene pool and relevant local host species.
\end{abstract}

Keywords: avian influenza; epidemiology; influenza A virus; migratory waterfowl; real-time RT-PCR; South Africa; surveillance; wild birds; zoonosis

\section{Introduction}

Avian influenza viruses (AIVs) continue to pose a threat to both animal and human health worldwide. Influenza A viruses belong to the family Orthomyxoviridae [1] and are classified into $18 \mathrm{HA}$ and 11 NA subtypes, of which $16 \mathrm{HA}$ (H1-H16) and 9 NA (N1-N9) subtypes circulate in avian species; H17N10 [2] and H18N11 [3] influenza A subtypes were detected in bats captured from South America using molecular methods. Wild birds of the orders Anseriformes (like ducks, geese and swans) and Charadriiformes (like gulls, waders and terns) are the main natural reservoir of influenza A virus subtypes [4,5]. AIVs of the H5 and H7 subtypes are further classified into low pathogenic avian influenza (LPAI) and highly pathogenic avian influenza (HPAI) viruses based on molecular markers and mortality rates in experimentally intravenously inoculated chickens [6]. In contrast to LPAI viruses, HPAI viruses cause high morbidity and mortality in poultry, but cause a spectrum of disease in wild 
birds. In addition, HPAI viruses have been reported to infect humans, resulting in high case mortality rates [7]. In 2005, HPAI viruses of the H5N1 subtype were detected in Asia, Europe, the Middle East and Africa, including South Africa, causing devastating economical losses due to numerous infections in both poultry and wild birds $[7,8]$. More recently, three other HPAI H5 subtypes emerged: H5N8 in 2014/15, H5N8 in 2016/17 and H5N6 in 2017/18. These HPAI viruses were most likely dispersed by wild migratory birds that travel long distances during their spring and autumn migration [9].

South Africa is a subtropical country located in the south of the African continent in the West Asian-East African and the East Atlantic migratory bird flyways. Due to the wide range of climatic types and habitats, South Africa has a wide variety of wild birds, both resident and migratory. Avian influenza surveillance efforts in South Africa have been very limited and mainly restricted to poultry species, including commercially kept ostriches. In June 2017, the HPAI H5N8 virus was first detected in domestic, captive and wild bird species in South Africa [10]. Due to the lack of surveillance activities prior to this detection, it is unknown when and how the virus first entered the country. However, the close proximity of commercial poultry farms to rivers and wetlands harboring high numbers of wild migratory waterfowl creates an ideal environment for wild-domestic transmission of AIVs. This study reports the results of active surveillance activities in KwaZulu-Natal Province in South Africa, a location previously marked as a high-risk area [11]. The aim of this project was to determine the temporal and spatial distribution of AIVs in waterfowl in this region.

\section{Materials and Methods}

\subsection{Ethical Approvals}

Bird catch, ring and release permits were obtained from Ezemvelo KwaZulu-Natal Wildlife Authority, Cascades, Pietermaritzburg, South Africa and KwaZulu-Natal Department of Agriculture and Rural Development, Veterinary Services, Cascades, Pietermaritzburg, South Africa. All procedures were conducted in full compliance with Section 20 of Animal Diseases Act 35 of 1984 and were approved by the South African Department of Agriculture, Forestry and Fisheries (Section 20 approval Reference. 12/11/1/5 granted to Prof. Mohamed Ezzat El Zowalaty). In addition, the research was conducted in compliance with the South African Council for Non-proliferation of Weapons of Mass Destruction (Ref. number NPC 018/416 granted to Prof. Mohamed Ezzat El Zowalaty). Ethical approvals were obtained from the Animal Research Ethics Committee of the University of KwaZulu-Natal (Reference AREC 071/017).

\subsection{Sample Collection}

Samples were collected from migratory waterfowl of the orders Anseriformes and Charadriformes captured from four different areas in the KwaZulu-Natal Province between February and December 2018 from different areas in Stanger (North Coast), Durban, Darvill Waste Water in Pietermaritzburg, and Newcastle Ponds (Figure 1). Birds were caught using mist netting and night-lighting.

Samples were collected using sterile swabs, transferred into $2 \mathrm{~mL}$ viral transport medium as described previously [12], and samples were stored at $-80^{\circ} \mathrm{C}$ until shipped and processed.

\subsection{Virus Detection, Isolation, Characterisation and Sequencing}

The samples were tested at the Erasmus Medical Center for the presence of avian influenza A viruses using matrix gene specific, and $\mathrm{H} 5$ and H7 HA gene specific real-time RT-PCR (RRT-PCR) assays with a cut-off for negative samples set at a cycle threshold $(\mathrm{Ct})$ value of 40 on the basis of the findings for multiple amplification curves as previously described [13]. Only positive samples were inoculated in two 11-day-old embryonated chicken eggs for 3 days (no blind passaging) and sequenced using Sanger (Thermo Fisher Scientific, Waltham, MA, USA) and MinION (Oxford Nanopore Technologies, Oxford, United Kingdom) techniques as previously described [14,15]. 


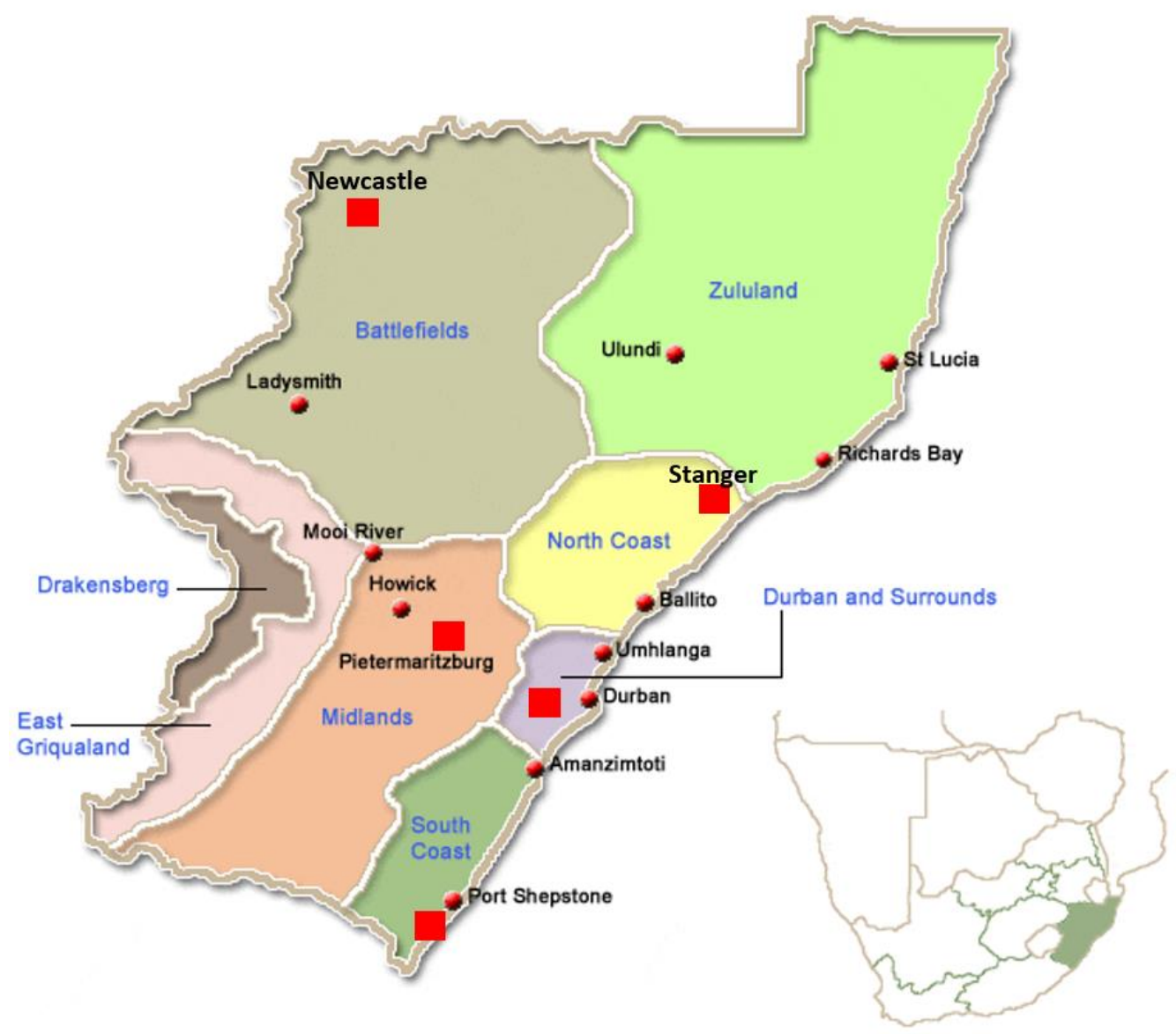

Figure 1. Geographic map showing sampling locations in this study.

\section{Results}

A total of 550 cloacal and oropharyngeal swabs were collected from 278 wild birds from 19 different species representing five families (Table 1, Figure 2).

\section{Distribution of sampling efforts}

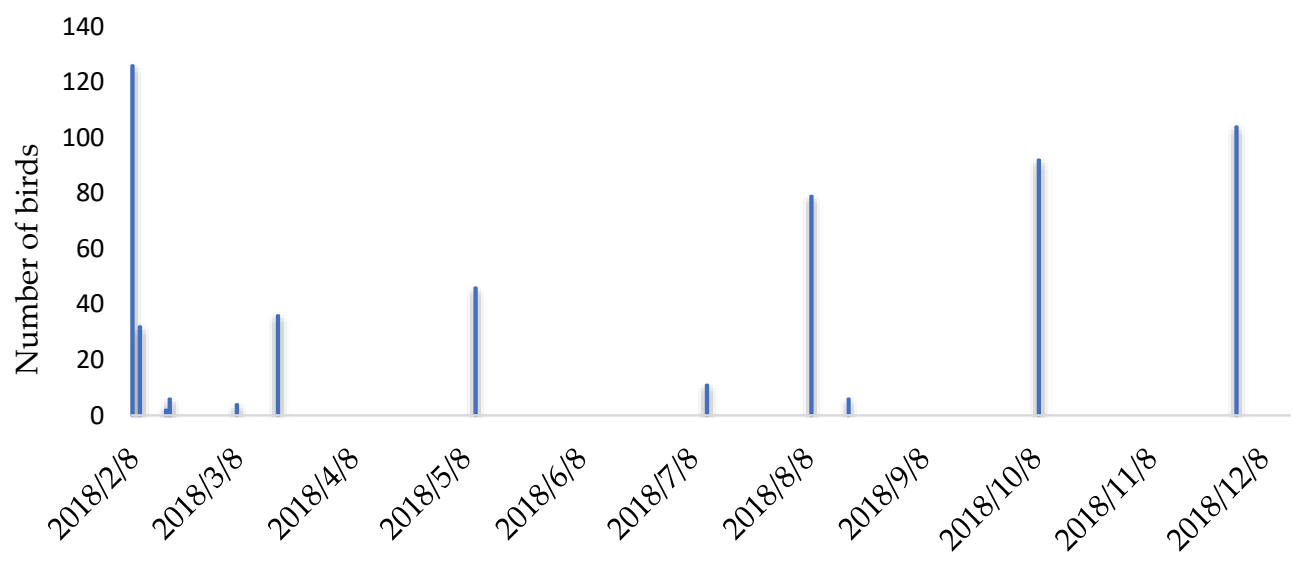

Date, 2018

Figure 2. Distribution of sample collection activities in number of birds (y-axis) in time (x-axis) during AI surveillance effort from wild birds in South Africa between February and December, 2018. 
Table 1. Detection of avian influenza virus in avian samples obtained from 19 species of waterfowl captured in South Africa in 2018.

\begin{tabular}{|c|c|c|c|c|c|}
\hline Bird Species & $\begin{array}{l}\text { No. of Birds } \\
\text { Captured }\end{array}$ & $\begin{array}{l}\text { No. of Cloacal } \\
\text { Samples } \\
\text { Tested }\end{array}$ & $\begin{array}{c}\text { No. of } \\
\text { Oropharyngeal } \\
\text { Samples Tested }\end{array}$ & $\begin{array}{l}\text { No. AIV } \\
\text { Positive by } \\
\text { RRT-PCR }\end{array}$ & $\begin{array}{l}\text { Bird Capture } \\
\text { Location }\end{array}$ \\
\hline $\begin{array}{c}\text { African Jacana } \\
\text { (Actophilornis africanus) }\end{array}$ & 1 & 1 & 1 & 0 & Stanger \\
\hline $\begin{array}{l}\text { Bahama Pintail Duck } \\
\text { (Anas bahamensis) }\end{array}$ & 3 & 3 & 3 & 0 & Durban \\
\hline $\begin{array}{l}\text { Blacksmith Lapwing } \\
\text { (Vanellus armatus) }\end{array}$ & 5 & 5 & 5 & 0 & $\begin{array}{l}\text { Newcastle }(\mathrm{n}=3) \\
\text { Pietermaritzburg } \\
\quad(\mathrm{n}=2)\end{array}$ \\
\hline $\begin{array}{l}\text { Carolina Wood Duck } \\
\text { (Aix sponsa) }\end{array}$ & 2 & 2 & 2 & 0 & Durban \\
\hline $\begin{array}{l}\text { Common Sandpiper } \\
\text { (Actitis hypoleucos) }\end{array}$ & 1 & 1 & 1 & 0 & Newcastle \\
\hline $\begin{array}{c}\text { Egyptian Geese } \\
\text { (Alopochen aegyptiaca) }\end{array}$ & 213 & 213 & 212 & $2 *$ & Durban \\
\hline $\begin{array}{l}\text { Fulvous Whistling Duck } \\
\text { (Dendrocygna bicolor) }\end{array}$ & 4 & 4 & 4 & 0 & Durban \\
\hline $\begin{array}{l}\text { Hawaiian Geese } \\
\text { (Branta sandvicensis) }\end{array}$ & 8 & 8 & 8 & 0 & Durban \\
\hline $\begin{array}{c}\text { Little stint } \\
\text { (Calidris minuta) }\end{array}$ & 5 & 5 & 5 & 0 & Newcastle \\
\hline $\begin{array}{l}\text { Mandarin Wood Duck } \\
\text { (Aix galericulata) }\end{array}$ & 1 & 1 & 1 & 0 & Durban \\
\hline $\begin{array}{l}\text { Mute Swan } \\
\text { (Cygnus olor) }\end{array}$ & 2 & 2 & 2 & 0 & Durban \\
\hline $\begin{array}{l}\text { Hooded Plover } \\
\text { (Thinornis rubricollis) }\end{array}$ & 2 & 2 & 1 & 0 & Durban \\
\hline $\begin{array}{l}\text { Red bill teal duck } \\
\text { (Anas erythrorhyncha) }\end{array}$ & 2 & 2 & 2 & 0 & Newcastle \\
\hline $\begin{array}{l}\text { Spotted Dikkop } \\
\text { (Burhinus capensis) }\end{array}$ & 1 & 1 & 1 & 0 & Durban \\
\hline $\begin{array}{l}\text { Spurwing Geese } \\
\text { (Plectropterus gambensis) }\end{array}$ & 7 & 7 & 7 & 0 & Durban \\
\hline $\begin{array}{l}\text { Yellow Billed Duck } \\
\text { (Anas undulata) }\end{array}$ & 3 & 3 & 3 & 0 & $\begin{array}{c}\text { Newcastle }(\mathrm{n}=1) \\
\text { Durban }(\mathrm{n}=2)\end{array}$ \\
\hline $\begin{array}{l}\text { Wood sandpiper } \\
\text { (Tringa glareola) }\end{array}$ & 3 & 3 & 3 & 0 & Stanger \\
\hline $\begin{array}{l}\text { White Faced Whistling } \\
\text { Duck } \\
\text { (Dendrocygna viduata) }\end{array}$ & 8 & 8 & 4 & 0 & Durban \\
\hline $\begin{array}{l}\text { Three-banded Plover } \\
\text { (Charadrius tricollaris) }\end{array}$ & 4 & 4 & 4 & 0 & Newcastle \\
\hline Unrecorded species & 3 & 3 & 3 & 0 & Not recorded \\
\hline Total & 278 & 278 & 272 & 2 & \\
\hline
\end{tabular}

* One cloacal and one oropharyngeal sample collected from two different healthy Egyptian geese.

The majority of birds were caught alive without any signs of disease. In addition, swabs were obtained from four Egyptian geese showing signs of disease (diarrhoea and lethargy) and two Egyptian geese found dead, all in the Durban area. The samples were collected from different sampling areas in KwaZulu-Natal Province (Figure 1). The majority of samples $(n=500)$ were obtained from birds captured in Durban, mainly Egyptian geese $(n=425)$, the rest of the samples were collected from species other than Egyptian geese from Stanger $(n=8)$, Pietermaritzburg $(n=4)$, and the Newcastle area $(\mathrm{n}=32)$; we were unable to determine the source location of 6 samples.

Two samples, a cloacal and an oropharyngeal swab sample, from two healthy juvenile Egyptian geese captured in the Durban area on 9 October 2018 tested positive for the presence of avian influenza A virus (2/278-0.7\%), but were negative for the presence of the H5 and H7 HA gene. Both samples contained low quantities of viral RNA (Ct values were 34.88 and 34.7) and could not be successfully cultured nor sequenced. Due to the initial high $\mathrm{Ct}$ value and the low sensitivity of HA-subtype specific RRT-PCR assays [16], no further subtyping was performed. 


\section{Discussion}

Surveillance and timely reporting are essential to increase our understanding of avian influenza epidemiology in wild birds and other hosts. This study reports the first AI surveillance efforts in wild waterfowl in the KwaZulu-Natal Province in South Africa, and showed evidence of a low incidence $(0.7 \%)$ of AI infections in the wild bird population in 2018 . Despite the fact that the two positive samples could not be subtyped, diagnostically excluding the $\mathrm{H} 5$ and $\mathrm{H} 7$ subtypes indicated that both were likely LPAI viruses of other subtypes. Wild bird surveillance efforts in South Africa are very limited [17-20], despite the fact that South Africa may be at a constant risk of HPAI introduction because of its wild bird flyway connection to and overlap with areas where HPAI viruses have/may become endemic, like Egypt [21], and infections in South African poultry have been described [19,22-24]. The factors, virologic, ornithologic, or epidemiologic that influence the dissemination of influenza viruses across regions by wild birds are poorly understood. In addition, some areas, like KwaZulu-Natal Province, have previously been marked as AIV high-risk areas based on wild bird movement [11]. The current status of avian influenza virus circulation in the South African wild bird population is unknown. To the authors' knowledge, the most recently published reports describing the detection of AIVs in living wild birds in South Africa (H1N8 and H4N2 in Egyptian geese) date back to 2007-2009 [19,20], apart from published detections of HPAI H5 viruses in outbreak-related wild bird screening [25]. However, based on sequence information deposited into public databases like Influenza Research Database (https://www.fludb.org), GenBank (https://www.ncbi.nlm.nih.gov/genbank) and Global Initiative on Sharing All Influenza Data (GISAID) (https://www.gisaid.org), the most recent detections of LPAI viruses in wild birds date back to 2012/2013. AIVs that were detected in South Africa thus far belong to Eurasian lineage viruses, although the genetic distance is quite large indicating intermediate viruses might have circulated in an unknown reservoir [19]. This is supported by other studies that have suggested that direct contact between Eurasian birds and local South African birds is a less likely route of avian influenza virus introduction into South Africa [26]. Compared to previous LPAI incidence data from South Africa (1.1\%) [26], this study shows a similar incidence of $0.7 \%$. However, because we targeted high-risk species in this study (e.g., Egyptian geese [19]), a higher incidence might be expected. Moreover, European AIV incidences are generally higher with clear seasonal peaks in late summer and autumn [27]. Possible explanations may include the difference in the ecology of AIV in the southern hemisphere compared to the northern hemisphere due to the milder winter, arid environment, the absence of migratory Palearctic duck species, and the flexible movement strategies of African wild bird populations that complicate the determination of (locally) involved hosts and the optimal timing of surveillance $[26,28]$. To address these issues, a broader range of species in representative numbers should be monitored regularly over a longer period of time.

Much of our knowledge about AIV dynamics is based on surveillance and epidemiological investigations in wild migratory birds. AIV surveillance in wild birds will help the understanding of the dynamics of AIV spread within and across continents and will, therefore, contribute to the development of successful control measures and strategies to manage and reduce the impact of (HPAI) virus outbreaks. In addition, continued surveillance efforts will help monitor the viral gene pool and trace the origins of influenza A viruses in South African wild birds and poultry and should remain a research priority as part of global surveillance programs.

Author Contributions: Conceptualization, M.E.E.Z. and R.A.M.F.; methodology, M.E.E.Z. and M.J.P.; software, M.J.P., M.E.E.Z.; validation, M.E.E.Z., M.J.P. and R.A.M.F.; formal analysis, M.E.E.Z. and M.J.P.; investigation, M.E.E.Z. and M.J.P.; resources, M.E.E.Z., R.A.M.F.; data curation, M.J.P., M.E.E.Z., R.A.M.F.; writing一original draft preparation, M.E.E.Z. and M.J.P.; writing—review and editing, M.E.E.Z., M.J.P., R.J.W., R.G.W. and R.A.M.F.; critical revisions and editing, M.J.P. and M.E.E.Z.; visualization, M.E.E.Z., M.J.P.; supervision, M.E.E.Z. and M.J.P.; project administration, M.J.P. and M.E.E.Z.; funding acquisition, R.A.M.F. and M.E.E.Z.

Funding: This project was funded by the United States NIH/NIAID Centers of Excellence for Influenza Research and Surveillance (contract no. HHSN272201400008C). M.E.E.Z. is an awardee of a CEIRS Training Program at St. Jude CEIRS under same contract. 
Acknowledgments: The authors would like to thank KwaZulu-Natlal Ezemvelo Wildlife Authority, Veterinary Services, technical staff and bird ringers for their cooperation and support during sampling. The authors thank Oanh Vuong and Rachel D. Scheuer from Department of Viroscience, Erasmus Medical Center, Rotterdam for technical assistance with analyzing the samples and the anonymous reviewers of this manuscript for their efforts. M.E.E.Z. is indebted to CEIRS Training Executive Committee and the Center for Research on Influenza Pathogenesis (CRIP) at Icahn School of Medicine at Mount Sinai, New York for receiving the CEIRS program award.

Conflicts of Interest: The authors declare no conflict of interest.

\section{References}

1. Shaw, M.; Palese, P. Orthomyxoviruses. In Fields Virology; Knipe, D.M., Howley, P.M., Eds.; Lippincott Williams \& Wilkins: Philadelphia, PA, USA, 2013.

2. Tong, S.; Li, Y.; Rivailler, P.; Conrardy, C.; Castillo, D.A.A.; Chen, L.M.; Recuenco, S.; Ellison, J.A.; Davis, C.T.; York, I.A.; et al. A distinct lineage of influenza A virus from bats. Proc. Natl. Acad. Sci. USA 2012, 109, 4269-4274. [CrossRef] [PubMed]

3. Tong, S.; Zhu, X.; Li, Y.; Shi, M.; Zhang, J.; Bourgeois, M.; Yang, H.; Chen, X.; Recuenco, S.; Gomez, J.; et al. New world bats harbor diverse influenza A viruses. PLoS Pathog. 2013, 9, e1003657. [CrossRef] [PubMed]

4. El Zowalaty, M.E.; Bustin, S.A.; Husseiny, M.I.; Ashour, H.M. Avian influenza: Virology, diagnosis and surveillance. Future Microbiol. 2013, 8, 1209-1227. [CrossRef] [PubMed]

5. Webster, R.G.; Bean, W.J.; Gorman, O.T.; Chambers, T.M.; Kawaoka, Y. Evolution and ecology of influenza A viruses. Microbiol. Rev. 1992, 56, 152-179. [PubMed]

6. Swayne, D.; Halvorson, D. Influenza. In Diseases of Poultry; Swayne, D.E., Ed.; Blackwell Publishing: Hoboken, NJ, USA, 2003; pp. 135-160.

7. World Health Organization. Cumulative Number of Confirmed Human Cases of Avian Influenza A/(H5N1) Reported to WHO, 2003-2019; World Health Organization: Geneva, Switzerland. Available online: https://www.who. int/influenza/human_animal_interface/2019_04_09_tableH5N1.pdf?ua=1 (accessed on 28 May 2019).

8. Sonnberg, S.; Webby, R.J.; Webster, R.G. Natural history of highly pathogenic avian influenza H5N1. Virus Res. 2013, 178, 63-77. [CrossRef] [PubMed]

9. Lycett, S.J.; Bodewes, R.; Pohlmann, A.; Banks, J.; Bányai, K.; Boni, M.F.; Bouwstra, R.; Breed, A.C.; Brown, I.H.; Chen, H.; et al. Role for migratory wild birds in the global spread of avian influenza H5N8. Science 2016, 354, 213-217.

10. Food and Agriculture Organization of the United Nations. 2016-2018 Spread of H5N8 Highly Pathogenic Avian Influenza (HPAI) in Sub-Saharan Africa: Epidemiological and Ecological Observations; FAO: Rome, Italy, 2018; Available online: http://www.fao.org/3/CA1209EN/ca1209en.pdf (accessed on 13 June 2019).

11. Cumming, G.; Hockey, P.; Bruinzeel, L.; Du Plessis, M. Wild bird movements and avian influenza risk mapping in southern Africa. Ecol. Soc. 2008, 13, 26. [CrossRef]

12. World Health Organization. Manual for the Laboratory Diagnosis and Virological Surveillance of Influenza; World Health Organization: Geneva, Switzerland. 2011. Available online: https://www.who.int/influenza/gisrs_ laboratory/manual_diagnosis_surveillance_influenza/en/ (accessed on 3 November 2017)

13. Munster, V.J.; Baas, C.; Lexmond, P.; Bestebroer, T.M.; Guldemeester, J.; Beyer, W.E.; de Wit, E.; Schutten, M.; Rimmelzwaan, G.F.; Osterhaus, A.D.; et al. Practical considerations for high-throughput influenza A virus surveillance studies of wild birds by use of molecular diagnostic tests. J. Clin. Microbiol. 2009, 47, 666-673. [CrossRef] [PubMed]

14. Poen, M.J.; Venkatesh, D.; Bestebroer, T.M.; Vuong, O.; Scheuer, R.D.; Oude Munnink, B.B.; de Meulder, D.; Richard, M.; Kuiken, T.; Koopmans, M.P.; et al. Co-circulation of genetically distinct highly pathogenic avian influenza A clade 2.3. 4.4 (H5N6) viruses in wild waterfowl and poultry in Europe and East Asia, 2017-18. Virus Evol. 2019, 5, vez004.

15. Venkatesh, D.; Poen, M.J.; Bestebroer, T.M.; Scheuer, R.D.; Vuong, O.; Chkhaidze, M.; Machablishvili, A.; Mamuchadze, J.; Ninua, L.; Fedorova, N.B.; et al. Avian influenza viruses in wild birds: Virus evolution in a multihost ecosystem. J. Virol. 2018, 92, e00433-18. [CrossRef]

16. Spackman, E.; Senne, D.A.; Myers, T.J.; Bulaga, L.L.; Garber, L.P.; Perdue, M.L.; Lohman, K.; Daum, L.T.; Suarez, D.L. Development of a real-time reverse transcriptase PCR assay for type A influenza virus and the avian H5 and H7 hemagglutinin subtypes. J. Clin. Microbiol. 2002, 40, 3256-3260. [CrossRef] [PubMed] 
17. Abolnik, C. Detection of a North American lineage H5 avian influenza virus in a South African wild duck: Research communication. Onderstepoort J. Vet. Res. 2007, 74, 177-180. [PubMed]

18. Abolnik, C.; Cornelius, E.; Bisschop, S.P.; Romito, M.; Verwoerd, D. Phylogenetic analyses of genes from South African LPAI viruses isolated in 2004 from wild aquatic birds suggests introduction by Eurasian migrants. Dev. Biol. 2006, 124, 189-199.

19. Abolnik, C.; Gerdes, G.H.; Sinclair, M.; Ganzevoort, B.W.; Kitching, J.P.; Burger, C.E.; Romito, M.; Dreyer, M.; Swanepoel, S.; Cumming, G.S.; et al. Phylogenetic analysis of influenza A viruses (H6N8, H1N8, H4N2, H9N2, H10N7) isolated from wild birds, ducks, and ostriches in South Africa from 2007 to 2009. Avian Dis. 2010, 54, 313-322. [CrossRef] [PubMed]

20. Gaidet, N.; Caron, A.; Cappelle, J.; Cumming, G.S.; Balança, G.; Hammoumi, S.; Cattoli, G.; Abolnik, C.; Servan de Almeida, R.; Gil, P.; et al. Understanding the ecological drivers of avian influenza virus infection in wildfowl: A continental-scale study across Africa. Proc. R. Soc. B Biol. Sci. 2011, 279, 1131-1141. [CrossRef] [PubMed]

21. Fasanmi, O.G.; Odetokun, I.A.; Balogun, F.A.; Fasina, F.O. Public health concerns of highly pathogenic avian influenza H5N1 endemicity in Africa. Vet. World 2017, 10, 1194. [CrossRef] [PubMed]

22. Abolnik, C. Molecular characterization of $\mathrm{H} 5 \mathrm{~N} 2$ avian influenza viruses isolated from South African ostriches in 2006. Avian Dis. 2007, 51, 873-879. [CrossRef] [PubMed]

23. Abolnik, C.; Bisschop, S.; Gerdes, T.; Olivier, A.; Horner, R. Outbreaks of avian influenza H6N2 viruses in chickens arose by a reassortment of H6N8 and H9N2 ostrich viruses. Virus Genes 2007, 34, 37-45. [CrossRef]

24. Abolnik, C.; Olivier, A.J.; Grewar, J.; Gers, S.; Romito, M. Molecular analysis of the 2011 HPAI H5N2 outbreak in ostriches, South Africa. Avian Dis. 2012, 56, 865-879. [CrossRef]

25. Abolnik, C.; Pieterse, R.; Peyrot, B.M.; Choma, P.; Phiri, T.P.; Ebersohn, K.; Heerden, C.V.; Vorster, A.A.; Zel, G.V.D.; Geertsma, P.J.; et al. The Incursion and Spread of Highly Pathogenic Avian Influenza H5N8 Clade 2.3. 4.4 Within South Africa. Avian Dis. 2018, 63, 149-156. [CrossRef]

26. Cumming, G.S.; Caron, A.; Abolnik, C.; Cattoli, G.; Bruinzeel, L.W.; Burger, C.E.; Cecchettin, K.; Chiweshe, N.; Mochotlhoane, B.; Mutumi, G.L.; et al. The ecology of influenza A viruses in wild birds in southern Africa. EcoHealth 2011, 8, 4-13. [CrossRef] [PubMed]

27. Latorre-Margalef, N.; Tolf, C.; Grosbois, V.; Avril, A.; Bengtsson, D.; Wille, M.; Osterhaus, A.D.; Fouchier, R.A.; Olsen, B.; Waldenström, J. Long-term variation in influenza A virus prevalence and subtype diversity in migratory mallards in northern Europe. Proc. R. Soc. B Biol. Sci. 2014, 281, 20140098. [CrossRef] [PubMed]

28. Caron, A.; de Garine-Wichatitsky, M.; Ndlovu, M.; Cumming, G.S. Linking avian communities and avian influenza ecology in southern Africa using epidemiological functional groups. Vet. Res. 2012, 43, 73. [CrossRef] [PubMed]

(C) 2019 by the authors. Licensee MDPI, Basel, Switzerland. This article is an open access article distributed under the terms and conditions of the Creative Commons Attribution (CC BY) license (http://creativecommons.org/licenses/by/4.0/). 